\title{
Fiscal Activism and Price Volatility: Evidence from Advanced and Emerging Economies ${ }^{*}$
}

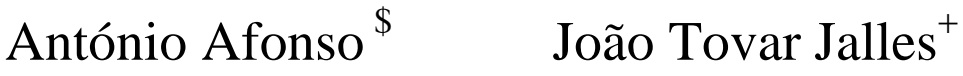

2016

\begin{abstract}
Using a panel of 54 countries between 1980 and 2013, we find empirical support for the view that changes in the fiscal policy stance (year-on-year change in the cyclically adjusted primary balance) have a significant positive correlation with inflation volatility. An increase in the volatility of discretionary fiscal policies by one standard deviation raises inflation volatility between 5 and 6 percent. Moreover, results using alternatively different inflation volatility proxies confirm that an expansionary fiscal stance increases price volatility. Another relevant outcome is that during an economic boom the harmful impact of fiscal activism on price volatility is soften (heightened), while the negative impact of fiscal activism on price stability is higher when fiscal policy is expansionary. Finally, fiscal activism fuels inflation volatility much more pronouncedly in emerging market economies vis-a-vis advanced economies.
\end{abstract}

JEL: C23, E31, E62, G01, H62

Keywords: volatility, fiscal policy, inflation, GARCH, Consensus Forecasts

\footnotetext{
* The opinions expressed herein are those of the authors and do not necessarily reflect those of their employers. Any remaining errors are the authors' sole responsibility.

\$ ISEG/ULisbon - University of Lisbon, Department of Economics; UECE - Research Unit on Complexity and Economics, R. Miguel Lupi 20, 1249-078 Lisbon, Portugal, email: aafonso@ iseg.utl.pt. UECE (Research Unit on Complexity and Economics) is financially supported by FCT (Fundação para a Ciência e a Tecnologia), Portugal. This article is part of the Strategic Project (UID/ECO/00436/2013). email: aafonso@iseg.utl.pt.

+ Centre for Globalization and Governance, Nova School of Business and Economics, Campus Campolide, Lisbon, 1099-032 Portugal. UECE - Research Unit on Complexity and Economics, R. Miguel Lupi 20, 1249-078 Lisbon, Portugal. email: joaojalles@gmail.com.,
} 


\section{Introduction}

Inflation volatility has been an important topic in the literature looking at the relationship between inflation and economic growth. On the one hand, several studies have concluded that high inflation (and associated high inflation volatility) are generally harmful to growth. On the other hand, only few studies have focused on disentangling the individual channels through which such effect occurs. High variability of inflation over time makes expectations over the future price level more uncertain. In a world with nominal contracts this induces risk premia for long-term arrangements, raises costs for hedging against inflation risks and leads to unanticipated redistribution of wealth. Thus, inflation volatility can impede growth even if inflation on average remains restrained (Friedman, 1977).

Judson and Orphanides (1999) found evidence that inflation volatility (measured by the standard deviation of intra-year inflation rates) has led to lower economic growth in a large panel of countries. Also, Froyen and Waud (1987) found that high inflation induces high inflation volatility and uncertainty in the USA, Germany, Canada and UK. For the latter two they also reported a negative impact of inflation uncertainty on economic growth. Similarly, Al-Marhubi (1998) found negative growth effects of conditional and unconditional inflation volatility for a panel of 78 countries. Blanchard and Simon (2001) found a strong positive link between inflation volatility and output volatility for large advanced countries.

In this paper, we empirically analyse the impact of the volatility of discretionary fiscal policies on the volatility of inflation, while taking other possible explanatory factors into account. This approach follows Fatas and Mihov (2003) who reported that discretionary fiscal policies have significantly contributed to output volatility in a wide range of countries and Furceri and Jalles (2016) who showed that increase fiscal stabilization reduces output fluctuations in a country-panel between 1980 and 2013.

We use a heterogeneous sample 54 countries covering both advanced and emerging economies between 1980 and 2013. By means of panel data techniques, this study finds empirical support for the view that changes in the fiscal policy stance (defined as the year-on-year change in the cyclically adjusted primary balance, in percent of GDP) show a significant positive correlation with inflation volatility. More specifically, heightened fiscal activism adversely affects price stability and an increase in the volatility of activist fiscal policies by one standard deviation raises inflation volatility between 5 and 6 percent. Moreover, results using alternatively 
different inflation volatility proxies confirm that an expansionary fiscal stance increases price volatility. Another relevant outcome is that during an economic boom the harmful impact of fiscal activism on price volatility is soften (heightened), while the negative impact of fiscal activism on price stability is higher when fiscal policy is expansionary. Finally, fiscal activism fuels inflation volatility much more pronouncedly in emerging market economies vis-a-vis advanced economies.

The remainder of the paper is organized as follows. Section 2 provides a survey of the related literature. Section 3 presents the empirical methodology. Section 4 reports and discusses our main results. The last section concludes.

\section{Literature Review}

There are several potential channels through which fiscal policies can affect inflation. The first one is the effect of prices' evolution on aggregate demand. The second, the spillover from public wages into private sector as well as taxes affecting marginal costs and private consumption. Notably, Afonso and Gomes (2014), looking at an OECD panel, report that the growth of public sector wages and of public sector employment positively affects the growth of

private sector wages. Thirdly, fiscal policy can affect inflation through public expectations regarding the ability of future governments to redeem the outstanding public debt.

On the one hand, the impacts of fiscal policies on inflation have been extensively addressed in the literature notably going back to Sargent and Wallace's (1981) unpleasant monetarist arithmetic. In that context, although the monetary authority presently keeps inflation low, if the fiscal authority sets the budget independently, then the monetary authority will be forced to create money and tolerate more inflation in the future.

On the other hand, a less orthodox view of how fiscal developments might impinge on the price level can be traced to the Fiscal Theory of the Price Level (FTPL), initially made popular by Leeper (1991), Sims (1994) and Woodford (1994, 1995). Leeper-Sims-Woodford argue that it will be then up to the government budget constraint to play a key role in the determination of the price level. Therefore, in this so-called "strong form" of the FTPL, fiscal policy may have a relevant role, at least as important as monetary policy, in determining the price level, affecting it independently of the money supply. 
In fact, there is also a renewed interest in countercyclical fiscal policy, as a possible policy measure to deal with the eventual limitations of monetary policy in a situation of very low interest rates and subdued growth. For instance, Tulip (2014) argues that countercyclical fiscal policy can help in stabilising the economy, in the absence of targeting higher inflation levels.

Regarding empirical studies on the link between budget balances and inflation, for instance, Catão and Terrones (2003), using a panel analysis for 107 countries over the period 1960-2001, report a positive link between budget deficits and inflation only in the case of developing countries with high levels of inflation. Fischer et al. (2002), looking at 133 countries between 1960 and 1996, also report such a link between fiscal imbalances and inflation for high inflation cases. More specifically, on volatility, Rother (2004) reports that for OECD countries between 1967 and 2001, fiscal policy volatility has increased inflation volatility, using notably GARCH models.

Bassetto and Butters (2010), for an OECD panel between1970 and2008, do not find evidence that budget deficits have preceded higher inflation. In this case, and depending on the country, the authors use either data for the general government or for the central government. On the other hand, Tiwari et al. (2013) use quarterly data for the period 1990-2013 for several OECD countries and report frequency domain causality from inflation to budget deficits and a long-run relationship for Belgium, and France.

In a VAR set up for 5 OECD countries (USA, 1961:Q1-2000:Q4; West Germany, 1961:Q1-1989:Q4; United Kingdom, 1964:Q1-2001:Q2; Canada, 1962:Q1-2001:Q4; Australia, 1964:Q1-2000:Q4) Perotti (2002) shows that the effect of government spending on the price level is positive, although mostly small and seldom statistically significant. In addition, Afonso and Sousa (2012) using a Bayesian Structural Vector Autoregression approach for the US, the UK, Germany and Italy, find that government spending shocks not have an effect on the price level.

Finally, in the context of a Dynamic Stochastic General Equilibrium model setup, de Graeve and von Heideken (2013), for the period 1966:Q1-2011:Q2, conjecture that concerns about fiscal inflation increase anticipated long-run inflation, notably as far as future projections of government debt are concerned. 


\section{Empirical Methodology and Data Issues}

This paper assesses the empirical link between a measure of inflation volatility and a measure of fiscal policy volatility for a panel of 54 advanced and emerging countries between 1980 and 2013 , controlling for a set of possible additional explanatory factors. ${ }^{1}$ Generally, in regression terms, this is equivalent to:

$$
\sigma_{t}^{\pi}=\alpha_{0}+\alpha_{1} \sigma_{t}^{F}+\mathbf{X}_{t}{ }^{\prime} \alpha_{3}+\varepsilon_{t}
$$

where $\sigma^{\pi}{ }_{t}, \sigma^{F}{ }_{t}$ denote inflation volatility and the volatility of discretionary fiscal policies, respectively. $X_{t}$ is a vector of control variables.

Several alternative measures for inflation volatility are used. The first measure and our baseline measure will consist of an unconditional proxy of inflation volatility based on a 5-year rolling standard deviation of the CPI inflation rate. This unconditional inflation volatility measure captures the extent of short-term fluctuations in inflation. The idea underlying this approach is that changes in discretionary fiscal policies either directly or indirectly induce reactions in inflation, making it more volatile in the short run.

Our second measure relies on setting up an appropriate inflation forecast model to capture the impact of discretionary fiscal policies on the uncertainty of expected inflation. The underlying assumption is that changes in discretionary fiscal policies make inflation forecasting more difficult translating into larger forecast errors. In a panel setting there is a trade-off between forecast accuracy and structural homogeneity to countries when generating a proxy for inflation expectations. Complex models would be able of produce quite accurate inflation forecasts for individual countries; however, these country models would most likely differ across countries, making any inference for the panel problematic. As a result, a time series approach is employed to generate a proxy for inflation expectations. An AR(1) model with $\operatorname{GARCH}(1,1)$ structure for residual variances is estimated at annual frequency, with the forecast error variance representing conditional inflation uncertainty. The conditional variances are corrected for a potentially distorting effect. Assuming that the level of the fiscal stance should have a systematic impact on the level of inflation, the unconditional variances of the two variables would be positively related.

\footnotetext{
${ }^{1}$ The list of countries is presented in the Appendix. The set of 54 countries is dictated by data availability, namely by the variable cyclically adjusted balance balanced provided by the IMF WEO database and used in this paper as the main input for generating our measure of discretionary fiscal policy, as explained below.
} 
Consequently, results from a regression involving the variances could suggest a strong relationship, reflecting the interaction of the levels. Our conditional inflation variances account for this possible interaction through the inclusion of the level of the fiscal stance in the level equation for inflation. The time series model for the inflation forecast takes the following form:

$$
\begin{aligned}
& \pi_{t}=\delta+\beta_{1} \pi_{t-1}+\beta_{2} F_{t}+\xi_{t} \\
& \sigma^{2}{ }_{t}=\psi+\theta_{1} \lambda^{2}{ }_{t-1}+{ }_{1} \sigma^{2}{ }_{t-1}
\end{aligned}
$$

where $\pi_{t}$ is the year-on-year inflation rate and $F_{t}$ is the fiscal stance. The conditional inflation volatility is given by the one-step-ahead standard deviation $\sigma_{t}$ for each forecast of the inflation rate.

The remainder of our measures of inflation volatility are based on inflation forecasts produced by Consensus Economics. In the past decade there has been a huge growth in published economic analysis emanating from banks, corporations and independent consultants around the world, and a parallel growth in "consensus forecasting" services which gather together information from these disparate private sources. Each month since 1989, the Consensus Economics service has published forecasts for major economic variables prepared by panels of 10-30 private sector forecasters and now covers 70 countries. Below the individual forecasts for each variable, the service publishes their arithmetic average, the "consensus forecast" for that variable. Consensus forecasts are known to be hard to beat. ${ }^{2}$ This means that, in practice, the most promising alternative to official forecasts for most users of economic forecasts is not some naive model, but a consensus of private sector forecasts. ${ }^{3}$ We use the $\operatorname{mean}^{4}$ of the private analysts' monthly consensus forecasts of the inflation rate for the current and next year for the period from September 1989 to December 2012. Every month (or every other month in the case of some emerging market economies) a new forecast is made of the inflation rate. For each year,

\footnotetext{
${ }^{2}$ While individual private sector forecasts may be subject to various behavioral biases (Batchelor and Dua, 1992), many of these are likely to be eliminated by pooling forecasts from several forecasters.

${ }^{3}$ This is recognized by Artis (1996), who makes a visual comparison of IMF and Consensus Economics forecasts for real GDP and CPI inflation, and concludes that there is "little difference between WEO and Consensus errors". In a similar vein, Loungani (2001) plots real IMF and Consensus Economics GDP forecasts for over 60 developed and developing countries in the 1990s, and notes that "the evidence points to near-perfect collinearity between private and official (multilateral) forecasts ..."

${ }^{4}$ The number of forecasters is greater than 10 for most countries and for the major industrialized countries the panelists are generally based in the countries they forecast.
} 
the sequence of forecasts is the 24 forecasts made between January of the previous year and December of the year in question. ${ }^{5}$

The third, fourth, fifth and sixth proxies of inflation volatility correspond to the 12-month averages and standard deviations for current year and year ahead forecasts. It is important to use higher frequency data to better capture the interactions between fiscal policies (that are usually only decided and implemented at the annual frequency) and monetary policies (see Melitz, 1997; von Hagen et al. 2001; van Aarle et al, 2003; and Muscatelli et al, 2002). The seventh and eighth measures are based on forecast revisions, which if forecasts were to be rational and efficient would be zero (by fully incorporating the information content available to forecasters at each point in time). We define the initial revision of the forecast of inflation rate as the change in the forecast between October and April of the previous year and the final revision as the change between October of the current year and April of the current year.

The correlations between our eight measures of inflation volatility are presented in Table A1 in the Appendix A. All our measures are positively correlated at the 1 percent statistical significance level.

To measure the volatility of discretionary fiscal policies, our analysis is based on changes in the fiscal policy stance. The fiscal policy stance is defined as the year-on-year change in the cyclically adjusted primary balance (CAPB) (in percent of GDP). ${ }^{6}$ Removing from the overall budget balance the effects of changes in interest payments and in the business cycle, reflects the net budgetary impact of activist fiscal policy measures. Our first measure of fiscal stance is captured by the absolute change in the CAPB between two consecutive years. Our second measure, similarly to inflation, is based on a 5-year rolling standard deviation of the CAPB.

Finally, our set of controls includes, most notably, the following variables. First, we control for the level of inflation (given by the CPI percentage change) since it has been observed empirically that inflation volatility is highly correlated with its level. Second, we include output gap (computed using the HP filter), reflecting the impact of aggregate demand. Third, we add

\footnotetext{
${ }^{5}$ For countries for which only bi-monthly forecasts are available, we use the preceding month forecast as values for the months for which forecast data is missing. A similar approach is taken in Loungani et al. (2013) and Jalles et al. (2015).

${ }^{6}$ Using the CAPB in percent of potential GDP does not qualitatively change our main results. We decided to use the CAPB measure over actual nominal GDP in order to avoid introducing additional (potential) measurement errors stemming from the use on an unobserved concept, potential GDP.
} 
total government expenditures (in percent of GDP), since large governments tend to reduce the volatility of output and inflation in response to demand shocks through the operation of automatic fiscal stabilizers (Martinez-Mongay, 2001; Furceri and Jalles, 2016). Fourth, given that the effect of monetary policies offsetting inflationary fiscal policies will induce itself price volatility, we control for the 5-year rolling standard deviation of broad money (M2) expressed in percent of GDP. Fifth, we add the nominal effective exchange rate since, in an open economy, the CPI inflation rate will in part be determined by price movements of foreign goods due to the direct inclusion of such goods in the consumption basket or through their use as intermediate inputs. On the one hand, inflation volatility is expected to increase with the volatility of the nominal exchange rate, foreign price volatility and the openness of the economy. On the other, with sticky domestic wages and prices, adjustments to shocks to the economy will occur to some extent through the exchange rate. In this situation, movements in the nominal exchange rate would substitute for changes in prices, implying a negative relationship between variations in the two variables. Thus, the overall effect is a priori not obvious. Finally, to account for the spillover from foreign prices into domestic prices the share of imports in GDP is also included.

The following, more detailed, regression equation is estimated:

$\sigma_{i t}{ }^{\pi}=\alpha_{0}+\lambda_{i}+\delta_{t}+\sum_{j=1}^{2} \beta_{j} \sigma_{i t-j}{ }^{\pi}+\sum_{j=0}^{1} \theta_{j} \pi_{i t-j}+\alpha_{3} \sigma_{i t}^{F}+\alpha_{4} g a p_{i t-1}+\alpha_{5} G_{i t}+\alpha_{6} \sigma_{i t-1}^{M}+\alpha_{7} \sigma_{i t-1}^{E R}+\alpha_{8} M_{i t-1}+\varepsilon_{i t}$

where $\lambda_{i}, \delta_{t}$ are country and time effects respectively, $\sigma_{i t}{ }^{\pi}$ is a measure of inflation volatility, $\pi_{i t}$ is the CPI inflation rate, $\sigma^{F}$ it is a measure of the fiscal stance, gap ${ }_{i t}$ is the output gap, $G_{i t}$ is the government expenditure (percent of GDP), $\sigma^{M}{ }_{i t}$ is the money volatility, $\sigma^{E R}{ }_{i t}$ is the nominal exchange rate volatility, $M_{i t}$ is the share of imports in GDP. ${ }^{7}$ Finally, $\varepsilon_{i t}$ stands for an iid error term satisfying the usual assumptions of zero mean and constant variance. Equation (3) will be estimated by OLS with heteroskedastic robust standard errors.

\footnotetext{
${ }^{7}$ Summary statistics of all variables are presented in Table A2 in the Appendix.
} 


\section{Empirical analysis}

\subsection{Stylized Facts}

Figure 1 presents a scatterplot of the two key variables in this study, using annual data. Inflation volatility, measured by the (log of the) 5-year rolling standard deviation of inflation rates, is presented along the $\mathrm{x}$-axis, while fiscal policy volatility, measured by the ( $\log$ of) absolute changes in the cyclically adjusted primary balance, is presented along the $y$-axis. Even though the scatter does not show a strong relationship, there appears to be some positive link between these two variables when other explanatory factors are not accounted for.

Figure 1: Fiscal policy volatility versus inflation volatility (all countries, years)

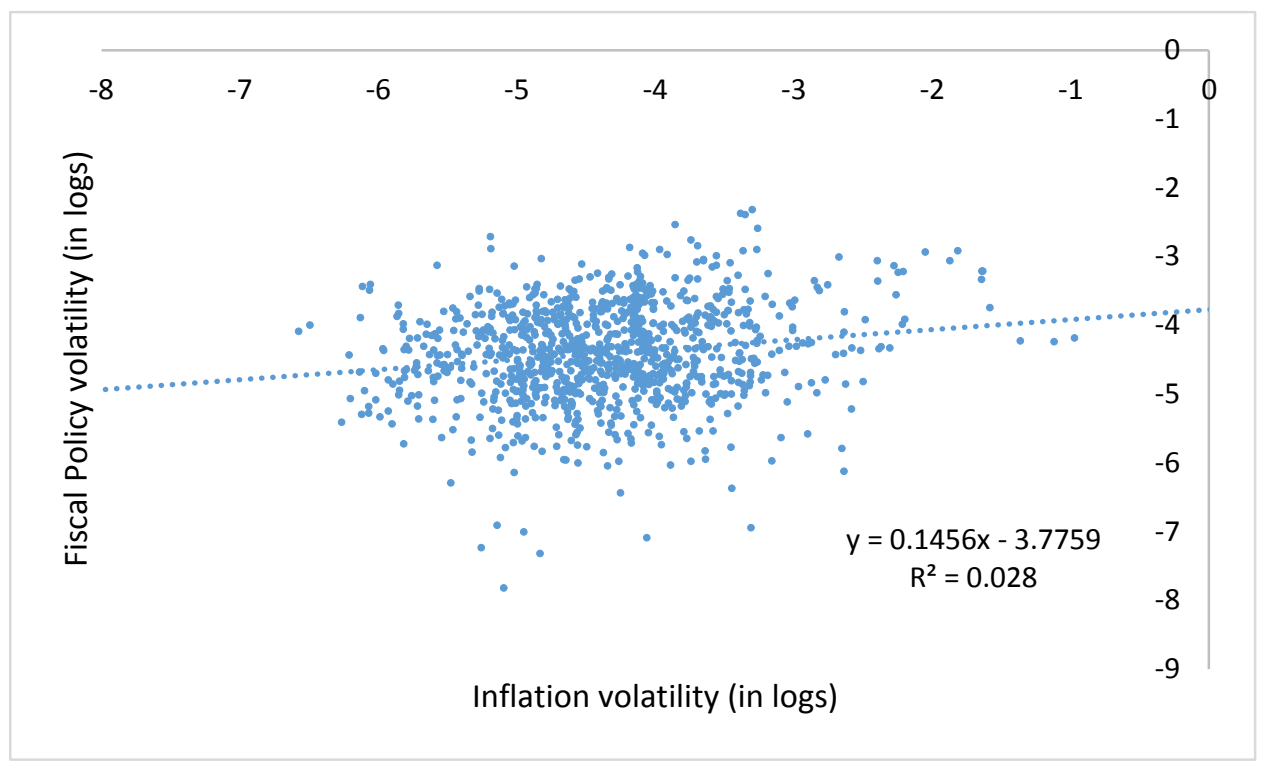

Note: authors' calculations.

\subsection{Baseline Regression}

We now move on into estimating Equation (3). Table 1 shows the results for three variants of the baseline specification where i) one lag of the dependent variable is included in the set of regressors, ii) one lag of the dependent variable and one lag of inflation rate are included in the set of regressors; iii) two lags of the dependent variable and one lag of inflation rate are included in the set of regressors. Moreover, we present OLS results without time or country fixed effects, with country fixed effects and with both country and time effects. Looking at the estimated coefficients, all of them have the expected signs when significant. More specifically, an increase in the level of inflation, a widening of the output gap (overheating), a higher share of imports in 
GDP bringing in the influence of external prices and higher nominal exchange rate volatility, all raise price volatility. Larger governments do seem to moderate fluctuations in prices but corresponding estimates are not statistically different from zero in this table. Also, volatility monetary policy, while yielding positive coefficient estimates is not statistically significant at usual levels. More importantly, our measure of fiscal stance (which in this case takes the form of the absolute value of annual changes in the CAPB) comes out with positive and statistically significant coefficients, meaning that heightened fiscal activism adversely affects price stability.

[Table 1]

The size of the impact of the volatility of activist fiscal policies on inflation variability can be important. Focusing on the last 3 columns of Table 1, the estimated coefficient for fiscal stance is between 0.025 and 0.033 . With a cross-country average of standard deviations of discretionary fiscal policies of 1.94 percentage points of GDP, this suggests that an increase in the volatility of activist fiscal policies by one standard deviation raises inflation volatility between 5 and 6 percent. To this direct impact, the indirect impact of the volatility of discretionary fiscal policies through their impact on output gap variability needs to be added. Based on a comprehensive survey of the literature, Hemming et al. (2002) report a likely size of the short-run fiscal multiplier between one half and one. Combining the average of these values (3/4) with the coefficient on output gap variability yields a potential additional impact between 1.5 and 3.5 percent, resulting in a total impact between 6.5 and 9.5 percent for the average across the sample. Feedback effects through the interaction of fiscal discretion with the other explanatory variables would increase the impact further.

In Table 2 we replace our measure of fiscal stance by the 5-year rolling standard deviation of the CAPB. Results are generally in line with those reported in Table 1. Now government size (proxied by public expenditures) yields a negative and statistically significant coefficient, confirming the theoretical role of automatic stabilizers in attenuating general fluctuations. For the remainder of the analysis we will use the absolute value of annual changes in the CAPB as our preferred measure for the fiscal stance and include country and time effects in our estimations.

[Table 2] 


\subsection{Robustness to alternative estimators and sensitivity to outliers}

It is important to subject our Equation (3) to alternative estimators that help correcting and overcoming some of the traditionally encountered econometric pitfalls. First, a positive correlation between inflation volatility and fiscal stance can also be the result of reverse causality, i.e., higher inflation volatility causing more activist fiscal policies. In addition, the results can be driven by a third, omitted variable that affects inflation volatility and the volatility of discretionary fiscal policies simultaneously. If we correctly specify the form of the variance (that is, if we account for serial correlation and possible cross-sectional heteroskedasticity and then use estimated cross-section residual variances as weights), then there exists a more efficient estimator (Feasible Generalized Least Squares, FGLS) than OLS.

Endogeneity between right and left hand side variables can be an additional concern. In an attempt to overcome this issue we resort to Arellano and Bond (1991) difference GMM estimator (DIF-GMM). ${ }^{8}$ However, as there are a number of limitations of DIF-GMM estimation ${ }^{9}$, under the assumptions set in Arellano and Bover (1995), the system-GMM estimator (SYS-GMM) can be used to alleviate the weak instruments problem. The SYS-GMM jointly estimates the equations in first differences, using as instruments lagged levels of the dependent and independent variables, and in levels, using as instruments the first differences of the regressors. ${ }^{10}$ Intuitively, the system-GMM estimator does not rely exclusively on the first-differenced equations, but exploits also information contained in the original equations in levels.

We also employ the panel-corrected standard error (PCSE) estimator by Beck and Katz (1995). Finally, we run of main regression equation with Driscoll-Kraay (1998) robust standard errors. This non-parametric technique assumes the error structure to be heteroskedastic, autocorrelated up to some lag and possibly correlated between the groups.

\footnotetext{
${ }^{8}$ The GMM approach estimates parameters directly from moment conditions imposed by the model. To enable identification the number of moment conditions should be at least as large as the number of unknown parameters. Moreover, the mechanics of the GMM approach relates to a standard instrumental variable estimator and also to issues such as instrumental validity and informativeness.

${ }^{9}$ For instance, the lagged levels of the series may be weak instruments for first differences, especially when they are highly persistent, or the variance of the individual effects is high relative to the variance of the transient shocks

${ }^{10}$ As far as information on the choice of lagged levels (differences) used as instruments in the differences (levels) equation, as work by Bowsher (2002) and, more recently Roddman (2009) has indicated, when it comes to moment conditions (as thus to instruments) more is not always better. The GMM estimators are likely to suffer from "overfitting bias" once the number of instruments approaches (or exceeds) the number of groups/countries (as a simple rule of thumb). In the present case, the choice of lags was directed by checking the validity of different sets of instruments and we rely on comparisons of first stage R-squares.
} 
Table 3 shows the results. We observe consistent results across the different estimators, from column (1) to (5). Specifically, higher inflation or nominal exchange rate fluctuations enhances price volatility. The same is true if fiscal policy becomes more active (in discretionary terms). The positive impact of the output gap is only statistically significant in the FGLS regression.

[Table 3]

Another important aspect to take into consideration is how much outliers drive our results, particularly when the sample is heterogeneous and includes emerging market economies that are usually characterized by spells of hyper-inflations every now and then. We use several alternative methods to exclude potentially adverse outliers form our estimations. First, we employ the Least Absolute Deviations (LAD) estimation method which is a robust method in the presence of outliers and asymmetric error terms (Bassett and Koenker, 1978). Second, we use the M estimation which was introduced by Huber (1973). Third, the S estimation that is a high breakdown value method introduced by Rousseeuw and Yohai (1984). Finally, the MM estimation, introduced by Yohai (1987), combines high breakdown value estimation and M estimation. It has both the high breakdown property and a higher statistical efficiency than $\mathrm{S}$ estimation.

Looking at Table 4, with the exception of the $\mathrm{S}$ estimator, the remaining show a positive and significant impact of fiscal activism on inflation volatility. The other regressors keep the previous signs and similar magnitudes.

[Table 4]

\subsection{Using alternative proxies of inflation volatility}

In this sub-section we allow for alternative measures of inflation volatility to play a role as the dependent variable. We consider the set of proxies discussed in Section 3, namely the GARCH $(1,1)$ implied volatility, the average and standard deviation of 12 months (over the current year and year-ahead) forecast errors using Consensus Economics forecasts of inflation and, finally, final and initial forecast revisions of inflation using the same source.

Table 5 includes the baseline for comparison purposes and shows that changes in the fiscal stance robustly increase price volatility. This means that fluctuations in both actual inflation data and also in inflation expectations, reflecting different horizons of uncertainty, are equally affected by changes in discretionary fiscal policy actions. 
[Table 5]

In Table 6 we repeat the same set of estimations as in Table 5 but we split our sample by income group into advanced and emerging countries. In general, fiscal activism in emerging market economies fuels inflation volatility much more pronouncedly compared to advanced countries. High inflation by itself has also a more damaging effect in price fluctuations in emerging markets than in advanced countries.

[Table 6]

\subsection{Fiscal activism, good and bad times and financial crises}

We go in exploring whether fiscal activism is different during good and bad times of the economic business cycle. To this end, we interact our measure of fiscal volatility with positive and negative output gap. We observe in Table 7 that during economic expansions (recessions) the detrimental effect of fiscal activism on price volatility is soften (heightened). Going one step further, and focusing on bad times or recessionary periods, we interact our fiscal stance measure with dummy variables for financial crises, banking crises and currency crises (retrieved from Leaven and Valencia, 2008, 2010). Particularly during currency crises, which themselves increase inflation volatility, discretionary fiscal policy actions tend to exacerbate the price volatility impact.

\section{[Table 7]}

\subsection{Fiscal activism and asymmetric effects}

Finally, does our measure of fiscal stance defined as the absolute value of annual changes in the CAPB have differentiated effects is those changes mean an improvement or a deterioration of the fiscal stance? We explore this by splitting our proxy for fiscal volatility into the absolute value of positive changes and the absolute value of negative changes. Table 8 shows that the negative impact of increased fiscal activism in price stability is particularly high during times of budgetary expansion. When the budgetary position is improving, that is, the CAPB improves between two years, by means of fiscal consolidation, the effect of discretionary fiscal actions on price volatility is not statistically different from zero.

[Table 8] 


\section{Conclusion}

The links between fiscal policy and inflation are important in terms of inflationary pressures from fiscal expansions and also regarding the potential instability effects of government activities on price volatility.

In his paper, we have used a panel sample of 54 countries covering both advanced and emerging economies between 1980 and 2013, and we found empirical support for the view that changes in the fiscal policy stance show a significant positive correlation with inflation volatility. In addition, after accounting for possible endogeneity between right and left hand side variables, using the difference GMM estimator, we still found similar results. Therefore, more active fiscal policy increases price volatility.

Moreover, we have also resorted to alternative measures of inflation volatility: GARCH $(1,1)$ implied volatility; the average and standard deviation of 12 months forecast errors using Consensus Economics forecasts; final and initial forecast revisions of inflation using the same source. Our results using different inflation volatility proxies confirm that expansionary fiscal stance augments price volatility.

Taking into account the two sub-samples of advanced and emerging economies, fiscal activism fuels inflation volatility much more pronouncedly in the case of emerging market economies vis-a-vis advanced economies.

Another relevant result relates to the fact that in a context of economic expansions (recessions) the harmful impact of fiscal activism on price volatility is soften (heightened). In the same vein, the negative impact of fiscal activism on price stability is higher when fiscal policy is expansionary. This has a useful policy implication since hints at the idea that discretionary fiscal policy can produce less price volatility in boom times. On the other hand, in the context of a currency crisis, discretionary fiscal policy can exacerbate price volatility. 


\section{References}

1. Afonso, A. and Gomes, P. (2014). "Interactions between private and public sector wages", Journal of Macroeconomics, 39, 97-112.

2. Afonso, A., Sousa, R. (2012). "The Macroeconomic Effects of Fiscal Policy", Applied Economics, 44 (34), 4439-4454.

3. Al-Marhubi, F. (1998), "Cross-country evidence on the link between inflation volatility and growth", Applied Economics, 30, 1317-1326.

4. Arellano, M. and O. Bover (1995), "Another look at the instrumental variable estimation of error-components models", Journal of Econometrics, 68, 29-51.

5. Arellano, M. and S. Bond (1991), "Some tests of specification for panel data: Monte Carlo evidence and an application to employment equations", Review of Economic Studies, 58, 277-297.

6. Artis, M.J. (1996), "How accurate are the IMF's short term forecasts? Another examination of the World Economic Outlook", IMF Research Department Working Paper.

7. Bassetto, M., Butters, R. (2010). "What is the relationship between large deficits andinflation in industrialized countries?"oEconomic Perspectives 3Q/2010, 83-100, Federal Reserve Bank of Chicago

8. Bassett, G., and Koenker, R. (1978), "Asymptotic Theory of Least Absolute Error Regression", Journal of the American Statistical Association, 73(363), 618-622.

9. Batchelor, R. and Dua, P. (1995), "Forecaster diversity and the benefits of combining forecasts", Management Science, 41, 1, 68-75.

10. Beck, N. and J. N. Katz (1995), What to do (and not to do) with time-series cross-section data, American Political Science Review 89, 634\{47.

11. Blanchard, O. and J. Simon (2001), "The Long and Large Decline in U.S. Output Volatility", Brookings Papers on Economic Activity, 1,135-164

12. Browsher, C. G. (2002), "On testing overidentifying restrictions in dynamic panel data models", CEPR Discussion Paper No. 3048, CEPR London.

13. Catão, L., Terrones, M. (2003). "Fiscal Deficits and Inflation”, IMF WP 03/65.

14. De Graeve, F., von Heideken, V. (2013). "Identifying fiscal inflation”, Sveriges Riksbank Working Paper Series, No. 273. 
15. Driscoll, J. and Kraay, A.: (1998), Consistent covariance matrix estimation with spatially dependent panel data, Review of Economics and Statistics 80(4), 549ñ560.

16. Fatas, A., and I. Mihov (2003), "The case for restricting fiscal policy discretion", Quarterly Journal of Economics, 4, 1419-1447

17. Fischer, S., Sahay, R., Végh, C. (2002). "Modern Hyper- and High Inflations." Journal of Economic Literature, 40 (3), 837-880.

18. Friedman, M. (1977), "Nobel lecture: Inflation and unemployment", Journal of Political Economy, 85, 451-472

19. Froyen, R. and R. Waud (1987), “An examination of aggregate price uncertainty in four countries and some implications for real output", International Economic Review, 28(2), 353372.

20. Furceri, D. and Jalles, J. T. (2016), "Determinants and Effects of Fiscal Stabilization: New Evidence from Time-Varying Estimates", forthcoming IMF Working Paper, Washington DC, USA

21. Hemming, Richard, Kell, Michael and Mahfouz, Selma (2002): The Effectiveness of Fiscal Policy in Stimulating Economic Activity - A Review of the Literature. IMF Working Paper 02/208

22. Huber, P.J. (1973), "Robust regression: Asymptotics, conjectures and Monte Carlo," Annals of Statistics, 1, 799- 821.

23. Jalles, J. T., Karibzhanov, I. and Loungani, P. (2015), "Cross-country Evidence on the Quality of Private Sector Fiscal Forecasts”, Journal of Macroeconomics, Vol. 45, pp. 186-201

24. Judson, R. and A. Orphanides (1999), "Inflation, Volatility and Growth", International Finance, 2(1), 117-138

25. Laeven, L. and Valencia, F. (2008). Systemic Banking Crises: A New Database. International Monetary Fund, IMF Working Papers, No 08/224.

26. Laeven, L.., and Valencia, F. (2010). Resolution of Banking Crises: The Good, the Bad, and the Ugly. International Monetary Fund, IMF Working Papers, No 10/146.

27. Leeper, E. (1991). "Equilibria Under 'Active' and 'Passive' Monetary and Fiscal Policies," Journal of Monetary Economics, 27 (1), 129-147.

28. Loungani, P. (2001), "How accurate are private sector forecasts? Cross-country evidence from Consensus Forecasts of output growth", International Journal of Forecasting, 17, 419-432. 
29. Loungani, P., H. Stekler and N. Tamirisa, 2013, "Information Rigidity in Growth Forecasts: Some Cross-Country Evidence,” International Journal of Forecasting, 29, 605-21.

30. Martinez-Mongay, C. (2001), "Some (un-)pleasant econometrics about the relationship between fiscal policy and macroeconomic stability. Stability-enhancing reforms of governments", mimeo, European Commission, Brussels

31. Melitz, J. (1997), "Some Cross-Country Evidence About Debt, Deficits and the Behaviour of Monetary and Fiscal Authorities”, CEPR Discussion Paper 1653.

32. Muscatelli, V. A.; Tirelli, P.; Trecroci, C. (2002), "Monetary and Fiscal Policy Interactions Over the Cycle: Some Empirical Evidence", CESifo Working Paper 817

33. Perotti, R. (2002). "Estimating the effects of fiscal policy in OECD countries", ECB WP 168.

34. Rousseeuw, P. J. and V. J. Yohai, (1984), "Robust Regression by Mean of S Estimators, Robust and Nonlinear Time Series Analysis, New York, 256-274

35. Roodman, D. M. (2009), "A note on the theme of too many instruments", Oxford Bulletin of Economics and Statistics, 71(1), 135-58.

36. Rother, P. (2004). "Fiscal policy and inflation volatility", ECB WP 317.

37. Sargent, T. and Wallace, N. (1981). "Some unpleasant monetarist arithmetic," Federal Reserve Bank of Minneapolis Quarterly Review, 1-17, Fall.

38. Sims, C. (1994). "A Simple Model for the Study on the Determination of the Price Level and the Interaction of Monetary and Fiscal Policy," Economic Theory, 4 (3), 381-399.

39. Tulip, P. (2014). "Fiscal Policy and the Inflation Target", International Journal of Central Banking, June, 63-96.

40. Yohai, V. (1987). "High Breakdown Point and High Efficiency Robust Estimates for Regression", The Annals of Statistics, 15 (20), 642-656.

41. van Aarle, Bas; Garretsen, Harry, and Niko Gobbin (2003), "Monetary and Fiscal Policy Transmission in the Euro area: Evidence from a Structural VAR Analysis”, Journal of Economics and Business, 55 (5-6), 609-638. .

42. Woodford, M. (1994). "Monetary Policy and Price Level Determinacy in a Cash-inAdvance Economy," Economic Theory, 4 (3), 345-380.

43. Woodford, M. (1995). "Price Level Determinacy without Control of Monetary Aggregate," Carnegie-Rochester Conference Series on Public Policy, 43 (1), 1-46. 
Table 1: Price Volatility and Fiscal Discretion (measured as the absolute value of fiscal

\begin{tabular}{|c|c|c|c|c|c|c|c|c|c|}
\hline Specification & (1) & (2) & (3) & (4) & (5) & (6) & (7) & $(8)$ & (9) \\
\hline Effects & No & Country & Time+country & No & Country & Time+country & No & Country & Time+country \\
\hline \multicolumn{10}{|l|}{ Regressors } \\
\hline $\begin{array}{l}\text { dep.var. (-1) } \\
\text { dep.var. (-2) }\end{array}$ & $\begin{array}{c}0.528 * * * \\
(0.022)\end{array}$ & $\begin{array}{c}0.425 * * * * \\
(0.023)\end{array}$ & $\begin{array}{c}0.429 * * * \\
(0.023)\end{array}$ & $\begin{array}{c}0.687 * * * \\
(0.022)\end{array}$ & $\begin{array}{c}0.588 * * * \\
(0.027)\end{array}$ & $\begin{array}{c}0.613 * * * \\
(0.027)\end{array}$ & $\begin{array}{c}0.797 * * * \\
(0.029) \\
-0.135 * * * \\
(0.023)\end{array}$ & $\begin{array}{c}0.686 * * * \\
(0.031) \\
-0.133 * * * \\
(0.023)\end{array}$ & $\begin{array}{c}0.700 * * * \\
(0.032) \\
-0.117 * * * \\
(0.023)\end{array}$ \\
\hline $\begin{array}{l}\text { inflation } \\
\text { inflation (-1) }\end{array}$ & $\begin{array}{c}0.055^{* * * *} \\
(0.008)\end{array}$ & $\begin{array}{c}0.076^{* * * *} \\
(0.009)\end{array}$ & $\begin{array}{c}0.074 * * * \\
(0.010)\end{array}$ & $\begin{array}{c}0.146 * * * \\
(0.009) \\
-0.129 * * * \\
(0.009)\end{array}$ & $\begin{array}{c}0.129 * * * \\
(0.010) \\
-0.100 * * * \\
(0.010)\end{array}$ & $\begin{array}{c}0.122 * * * \\
(0.010) \\
-0.114 * * * \\
(0.011)\end{array}$ & $\begin{array}{c}0.150 * * * \\
(0.009) \\
-0.121 * * * \\
(0.009)\end{array}$ & $\begin{array}{c}0.135 * * * \\
(0.009) \\
-0.093 * * * \\
(0.010)\end{array}$ & $\begin{array}{c}0.129 * * * \\
(0.010) \\
-0.108 * * * \\
(0.010)\end{array}$ \\
\hline fiscal stance & $\begin{array}{c}0.016 \\
(0.015)\end{array}$ & $\begin{array}{c}0.031^{* *} \\
(0.013)\end{array}$ & $\begin{array}{c}0.027^{* *} \\
(0.014)\end{array}$ & $\begin{array}{c}0.027 * * \\
(0.013)\end{array}$ & $\begin{array}{c}0.035^{* * * *} \\
(0.012)\end{array}$ & $\begin{array}{c}0.032 * * \\
(0.013)\end{array}$ & $\begin{array}{c}0.038 * * * \\
(0.013)\end{array}$ & $\begin{array}{c}0.043 * * * \\
(0.012)\end{array}$ & $\begin{array}{c}0.039 * * * \\
(0.013)\end{array}$ \\
\hline output gap & $\begin{array}{l}0.029^{*} \\
(0.015)\end{array}$ & $\begin{array}{c}0.031 \text { *** } \\
(0.014)\end{array}$ & $\begin{array}{c}0.025 \\
(0.016)\end{array}$ & $\begin{array}{c}0.054 * * * \\
(0.013)\end{array}$ & $\begin{array}{c}0.046^{* * * *} \\
(0.013)\end{array}$ & $\begin{array}{c}0.052^{* * * *} \\
(0.015)\end{array}$ & $\begin{array}{c}0.053^{* * * *} \\
(0.013)\end{array}$ & $\begin{array}{c}0.047 * * * \\
(0.013)\end{array}$ & $\begin{array}{c}0.056^{* * * *} \\
(0.015)\end{array}$ \\
\hline gov.expenditures & $\begin{array}{c}-0.005^{* *} * \\
(0.002)\end{array}$ & $\begin{array}{l}-0.009 \\
(0.007)\end{array}$ & $\begin{array}{l}-0.011 \\
(0.008)\end{array}$ & $\begin{array}{l}-0.003 \\
(0.002)\end{array}$ & $\begin{array}{c}-0.012^{*} \\
(0.007)\end{array}$ & $\begin{array}{c}-0.018 * * \\
(0.007)\end{array}$ & $\begin{array}{c}-0.004 * * \\
(0.002)\end{array}$ & $\begin{array}{l}-0.009 \\
(0.007)\end{array}$ & $\begin{array}{c}-0.015^{* *} \\
(0.007)\end{array}$ \\
\hline sd.money & $\begin{array}{c}0.001 \\
(0.005)\end{array}$ & $\begin{array}{c}0.006 \\
(0.006)\end{array}$ & $\begin{array}{c}0.003 \\
(0.006)\end{array}$ & $\begin{array}{c}0.003 \\
(0.005)\end{array}$ & $\begin{array}{c}0.002 \\
(0.005)\end{array}$ & $\begin{array}{c}0.005 \\
(0.006)\end{array}$ & $\begin{array}{c}0.004 \\
(0.004)\end{array}$ & $\begin{array}{c}0.002 \\
(0.005)\end{array}$ & $\begin{array}{c}0.005 \\
(0.005)\end{array}$ \\
\hline sd NEER (-1) & $\begin{array}{c}0.023 * * * \\
(0.002)\end{array}$ & $\begin{array}{c}0.030 * * * \\
(0.002)\end{array}$ & $\begin{array}{c}0.030 * * * \\
(0.002)\end{array}$ & $\begin{array}{c}0.013 * * * \\
(0.002)\end{array}$ & $\begin{array}{c}0.019 * * * \\
(0.002)\end{array}$ & $\begin{array}{c}0.017 * * * \\
(0.003)\end{array}$ & $\begin{array}{c}0.012 * * * \\
(0.002)\end{array}$ & $\begin{array}{c}0.019 * * * \\
(0.002)\end{array}$ & $\begin{array}{c}0.017 * * * \\
(0.002)\end{array}$ \\
\hline imports_gdp (-1) & $\begin{array}{c}0.004 * * * \\
(0.001)\end{array}$ & $\begin{array}{c}0.000 \\
(0.004)\end{array}$ & $\begin{array}{l}-0.003 \\
(0.005)\end{array}$ & $\begin{array}{c}0.002 * * \\
(0.001)\end{array}$ & $\begin{array}{l}-0.006 \\
(0.004)\end{array}$ & $\begin{array}{l}-0.004 \\
(0.005)\end{array}$ & $\begin{array}{l}0.002^{*} \\
(0.001)\end{array}$ & $\begin{array}{l}-0.007 * \\
(0.004)\end{array}$ & $\begin{array}{l}-0.005 \\
(0.005)\end{array}$ \\
\hline Observations & 723 & 723 & 723 & 723 & 723 & 723 & 723 & 723 & 723 \\
\hline$R$-squared & 0.782 & 0.835 & 0.848 & 0.833 & 0.857 & 0.872 & 0.841 & 0.864 & 0.877 \\
\hline
\end{tabular}

Note: OLS regression with different sets of time and country effects as identified in the second row. Robust standard errors in parenthesis. *,**,*** denote statistical significance at the 10,5 , and 1 percent levels, respectively.

Constant term was estimated by omitted for reasons of parsimony.

Table 2: Price Volatility and Fiscal Discretion (measured as 5-year rolling standard deviation of fiscal stance)

\begin{tabular}{|c|c|c|c|c|c|c|c|c|c|}
\hline Specification & $(1)$ & $(2)$ & (3) & $(4)$ & $(5)$ & $(6)$ & $(7)$ & $(8)$ & $(9)$ \\
\hline Regressors & & & & & & & & & \\
\hline $\begin{array}{l}\text { dep.var. }(-1) \\
\text { dep.var. }(-2)\end{array}$ & $\begin{array}{c}0.535 * * * \\
(0.022)\end{array}$ & $\begin{array}{c}0.448 * * * \\
(0.024)\end{array}$ & $\begin{array}{c}0.460 * * * \\
(0.025)\end{array}$ & $\begin{array}{c}0.701 * * * \\
(0.021)\end{array}$ & $\begin{array}{c}0.638 * * * \\
(0.025)\end{array}$ & $\begin{array}{c}0.656 * * * \\
(0.025)\end{array}$ & $\begin{array}{c}0.749 * * * \\
(0.026) \\
-0.060 * * * \\
(0.019)\end{array}$ & $\begin{array}{c}0.691 * * * \\
(0.028) \\
-0.076^{* * *} \\
(0.019)\end{array}$ & $\begin{array}{c}0.711 * * * \\
(0.028) \\
-0.079 * * * \\
(0.019)\end{array}$ \\
\hline inflation & $\begin{array}{c}0.071 * * * \\
(0.009)\end{array}$ & $\begin{array}{c}0.098 * * * \\
(0.010)\end{array}$ & $\begin{array}{c}0.097 * * * \\
(0.010)\end{array}$ & $\begin{array}{c}0.157 * * * * \\
(0.009)\end{array}$ & $\begin{array}{c}0.157 * * * \\
(0.009)\end{array}$ & $\begin{array}{c}0.150 * * * \\
(0.009)\end{array}$ & $\begin{array}{c}0.159 * * * \\
(0.009)\end{array}$ & $\begin{array}{c}0.160^{* * *} * \\
(0.009)\end{array}$ & $\begin{array}{c}0.153 * * * \\
(0.009)\end{array}$ \\
\hline inflation (-1) & & & & $\begin{array}{c}-0.146 * * * \\
(0.008)\end{array}$ & $\begin{array}{c}-0.135 * * * \\
(0.009)\end{array}$ & $\begin{array}{c}-0.143 * * * \\
(0.009)\end{array}$ & $\begin{array}{c}-0.141 * * * \\
(0.008)\end{array}$ & $\begin{array}{c}-0.129 * * * \\
(0.009)\end{array}$ & $\begin{array}{c}-0.137 * * * \\
(0.009)\end{array}$ \\
\hline fiscal stance & $\begin{array}{c}0.137 * * * \\
(0.029)\end{array}$ & $\begin{array}{c}0.190 * * * \\
(0.033)\end{array}$ & $\begin{array}{c}0.172 * * * \\
(0.034)\end{array}$ & $\begin{array}{c}0.089 * * * \\
(0.025)\end{array}$ & $\begin{array}{c}0.116^{* * * *} \\
(0.029)\end{array}$ & $\begin{array}{c}0.103^{* * * *} \\
(0.030)\end{array}$ & $\begin{array}{c}0.085^{* * *} * \\
(0.025)\end{array}$ & $\begin{array}{c}0.109 * * * \\
(0.029)\end{array}$ & $\begin{array}{c}0.099 * * * \\
(0.029)\end{array}$ \\
\hline output gap & $\begin{array}{c}0.022 \\
(0.017)\end{array}$ & $\begin{array}{c}0.022 \\
(0.017)\end{array}$ & $\begin{array}{c}0.030 \\
(0.019)\end{array}$ & $\begin{array}{c}0.053 * * * \\
(0.015)\end{array}$ & $\begin{array}{c}0.044 * * * \\
(0.015)\end{array}$ & $\begin{array}{c}0.060 \text { *** } \\
(0.016)\end{array}$ & $\begin{array}{c}0.052 * * * \\
(0.015)\end{array}$ & $\begin{array}{c}0.044 * * * \\
(0.015)\end{array}$ & $\begin{array}{c}0.059 * * * \\
(0.016)\end{array}$ \\
\hline gov.expenditures & $\begin{array}{c}-0.011 * * * \\
(0.003)\end{array}$ & $\begin{array}{l}-0.007 \\
(0.011)\end{array}$ & $\begin{array}{l}-0.007 \\
(0.011)\end{array}$ & $\begin{array}{c}-0.008 * * * \\
(0.002)\end{array}$ & $\begin{array}{l}-0.018^{*} \\
(0.009)\end{array}$ & $\begin{array}{c}-0.019^{* * *} \\
(0.010)\end{array}$ & $\begin{array}{c}-0.009 * * * \\
(0.002)\end{array}$ & $\begin{array}{l}-0.016^{*} \\
(0.009)\end{array}$ & $\begin{array}{l}-0.017 * \\
(0.009)\end{array}$ \\
\hline sd.money & $\begin{array}{l}-0.003 \\
(0.007)\end{array}$ & $\begin{array}{l}-0.003 \\
(0.008)\end{array}$ & $\begin{array}{l}-0.007 \\
(0.008)\end{array}$ & $\begin{array}{l}-0.008 \\
(0.006)\end{array}$ & $\begin{array}{l}-0.006 \\
(0.007)\end{array}$ & $\begin{array}{l}-0.001 \\
(0.007)\end{array}$ & $\begin{array}{c}-0.008 \\
(0.006)\end{array}$ & $\begin{array}{l}-0.005 \\
(0.007)\end{array}$ & $\begin{array}{c}0.000 \\
(0.007)\end{array}$ \\
\hline $\begin{array}{l}\text { Observations } \\
R \text {-squared }\end{array}$ & $\begin{array}{c}806 \\
0.816\end{array}$ & $\begin{array}{c}806 \\
0.842 \\
\end{array}$ & $\begin{array}{c}806 \\
0.853 \\
\end{array}$ & $\begin{array}{c}805 \\
0.869\end{array}$ & $\begin{array}{c}805 \\
0.880\end{array}$ & $\begin{array}{c}805 \\
0.890\end{array}$ & $\begin{array}{c}805 \\
0.871\end{array}$ & $\begin{array}{c}805 \\
0.883\end{array}$ & $\begin{array}{c}805 \\
0.892 \\
\end{array}$ \\
\hline
\end{tabular}

Note: OLS regression with different sets of time and country effects as identified in the second row. Robust standard errors in parenthesis. $* * *, * * *$ denote statistical significance at the 10,5 , and 1 percent levels, respectively.

Constant term was estimated by omitted for reasons of parsimony. 
Table 3: Price Volatility and Fiscal Discretion (measured as the absolute value of fiscal stance), alternative estimators

\begin{tabular}{|c|c|c|c|c|c|}
\hline Specification & (1) & $(2)$ & (3) & (4) & (5) \\
\hline Estimator & $\begin{array}{c}\text { Generalized Least } \\
\text { Squares } \\
\end{array}$ & $\begin{array}{c}\text { Driscoll Kraay } \\
\text { Robust Estimation }\end{array}$ & $\begin{array}{l}\text { Panel Corrected } \\
\text { Standard Errors } \\
\end{array}$ & Difference GMM & System GMM \\
\hline \multicolumn{6}{|l|}{ Regressors } \\
\hline dep.var. (-1) & $\begin{array}{c}0.749^{* * * *} \\
(0.031)\end{array}$ & $\begin{array}{c}0.705 * * * \\
(0.099)\end{array}$ & $\begin{array}{c}0.615^{* * * *} \\
(0.049)\end{array}$ & $\begin{array}{c}0.611^{* * * *} \\
(0.238)\end{array}$ & $\begin{array}{c}0.535^{* * * *} \\
(0.158)\end{array}$ \\
\hline dep.var. (-2) & $\begin{array}{c}-0.155^{* * * *} \\
(0.026)\end{array}$ & $\begin{array}{c}-0.134 * * \\
(0.050)\end{array}$ & $\begin{array}{c}-0.092 * * * \\
(0.027)\end{array}$ & $\begin{array}{c}-0.512 * * * \\
(0.157)\end{array}$ & $\begin{array}{l}-0.114^{*} \\
(0.069)\end{array}$ \\
\hline inflation & $\begin{array}{c}0.122 * * * \\
(0.007)\end{array}$ & $\begin{array}{c}0.121 * * * \\
(0.026)\end{array}$ & $\begin{array}{c}0.115 * * * \\
(0.015)\end{array}$ & $\begin{array}{c}0.117 * * * \\
(0.023)\end{array}$ & $\begin{array}{c}0.119 * * * \\
(0.035)\end{array}$ \\
\hline inflation (-1) & $\begin{array}{c}-0.076^{* * * *} \\
(0.007)\end{array}$ & $\begin{array}{c}-0.090^{* * * *} \\
(0.025)\end{array}$ & $\begin{array}{c}-0.079 * * * \\
(0.015)\end{array}$ & $\begin{array}{c}0.029 \\
(0.054)\end{array}$ & $\begin{array}{l}-0.056 \\
(0.038)\end{array}$ \\
\hline fiscal stance & $\begin{array}{c}0.017 * * * \\
(0.007)\end{array}$ & $\begin{array}{c}0.033 * * * \\
(0.009)\end{array}$ & $\begin{array}{l}0.029 * \\
(0.015)\end{array}$ & $\begin{array}{c}0.135 * * * \\
(0.050)\end{array}$ & $\begin{array}{c}0.038^{* *} \\
(0.018)\end{array}$ \\
\hline output gap & $\begin{array}{c}0.016 * * * \\
(0.006)\end{array}$ & $\begin{array}{l}0.023 \\
(0.017)\end{array}$ & $\begin{array}{l}0.020 \\
(0.013)\end{array}$ & $\begin{array}{c}0.037 \\
(0.029)\end{array}$ & $\begin{array}{c}0.028 \\
(0.020)\end{array}$ \\
\hline gov.expenditures & $\begin{array}{c}-0.002 \\
(0.004)\end{array}$ & $\begin{array}{l}-0.004 \\
(0.006)\end{array}$ & $\begin{array}{l}-0.005 \\
(0.008)\end{array}$ & $\begin{array}{c}0.022 \\
(0.027)\end{array}$ & $\begin{array}{l}-0.019 \\
(0.014)\end{array}$ \\
\hline sd.money & $\begin{array}{c}0.005 \\
(0.003)\end{array}$ & $\begin{array}{c}0.002 \\
(0.002)\end{array}$ & $\begin{array}{c}0.003 \\
(0.004)\end{array}$ & $\begin{array}{l}-0.028 \\
(0.048)\end{array}$ & $\begin{array}{c}0.001 \\
(0.013)\end{array}$ \\
\hline sd NEER (-1) & $\begin{array}{c}0.007 * * \\
(0.003)\end{array}$ & $\begin{array}{c}0.019 * * * \\
(0.006)\end{array}$ & $\begin{array}{c}0.022 * * * \\
(0.004)\end{array}$ & $\begin{array}{l}0.036^{*} \\
(0.020)\end{array}$ & $\begin{array}{c}0.034 * * * \\
(0.009)\end{array}$ \\
\hline imports_gdp (-1) & $\begin{array}{c}0.002 \\
(0.002)\end{array}$ & $\begin{array}{l}-0.001 \\
(0.003)\end{array}$ & $\begin{array}{c}0.000 \\
(0.009)\end{array}$ & $\begin{array}{c}0.004 \\
(0.013)\end{array}$ & $\begin{array}{c}0.003 \\
(0.007)\end{array}$ \\
\hline $\begin{array}{l}\text { Observations } \\
A R(1))\end{array}$ & 848 & 848 & 848 & $\begin{array}{c}794 \\
0.020\end{array}$ & $\begin{array}{c}848 \\
0.002\end{array}$ \\
\hline$A R(2)$ & & & & 0.146 & 0.747 \\
\hline Hansen ( $p$-value) & & & & 0.863 & 0.751 \\
\hline
\end{tabular}

Note: Estimation using alternative estimators as identified in the second row. Robust standard errors in parenthesis.

$\mathrm{AR}(1)$ and AR(2) denote the p-values for the first and second order serial correlation in the residuals. The Hansen pvalue tests the null hypothesis of correct model specification and valid overidentifying restrictions, that is validity of the instruments. $* * *, * * *$ denote statistical significance at the 10,5 , and 1 percent levels, respectively. Constant term was estimated by omitted for reasons of parsimony.

Table 4: Price Volatility and Fiscal Discretion (measured as the absolute value of fiscal stance), outlier robust

\begin{tabular}{l|cccc}
\hline Specification & $(1)$ & $(2)$ & $(3)$ & $(4)$ \\
\hline Estimator & LAD & $\mathrm{M}$ & $\mathrm{S}$ & $\mathrm{MM}$ \\
\hline Regressors & & & & \\
\hline dep.var. (-1) & $0.495^{* * *}$ & $0.761^{* * *}$ & $0.947^{* * *}$ & $0.883^{* * *}$ \\
inflation & $(0.018)$ & $(0.036)$ & $(0.024)$ & $(0.025)$ \\
& $0.052^{* * *}$ & $0.030^{* * *}$ & $0.018^{* * *}$ & $0.025^{* * * *}$ \\
fiscal stance & $(0.007)$ & $(0.007)$ & $(0.006)$ & $(0.005)$ \\
& $0.017 *$ & $0.015^{* *}$ & 0.002 & $0.014^{* *}$ \\
output gap & $(0.010)$ & $(0.007)$ & $(0.006)$ & $(0.006)$ \\
& $0.021^{* *}$ & $0.035^{* * *}$ & $0.010^{*}$ & $0.020^{* * *}$ \\
gov.expenditures & $(0.009)$ & $(0.008)$ & $(0.005)$ & $(0.007)$ \\
& -0.002 & -0.002 & $-0.001 *$ & -0.002 \\
sd NEER (-1) & $(0.002)$ & $(0.001)$ & $(0.001)$ & $(0.001)$ \\
& $0.021^{* * *}$ & $0.009^{* * *}$ & $-0.004^{* *}$ & 0.002 \\
imports_gdp (-1) & $(0.002)$ & $(0.003)$ & $(0.002)$ & $(0.002)$ \\
& $0.004 * * *$ & $0.002^{* * *}$ & -0.000 & $0.001 *$ \\
Observations & $(0.001)$ & $(0.000)$ & $(0.000)$ & $(0.000)$ \\
$R$-squared & 839 & 848 & 848 & 848 \\
\hline
\end{tabular}

Note: Estimation using alternative estimators as identified in the second row. The LAD denotes the least-adbsolute deviation; the M denotes the Huber (1973) estimator; the S denotes the high breakdown value method introduced by Rousseew and Yohai (1984); the MM denotes the method of moments estimator due to Yohai (1987) — see main text for details. Robust standard errors in parenthesis. *, **, *** denote statistical significance at the 10, 5, and 1 percent levels, respectively. Constant term was estimated by omitted for reasons of parsimony. 
Table 5: Price Volatility and Fiscal Discretion (measured as the absolute value of fiscal stance), alternative dependent variables

\begin{tabular}{|c|c|c|c|c|c|c|c|c|}
\hline Specification & $(1)$ & $(2)$ & (3) & (4) & $(5)$ & $(6)$ & $(7)$ & $(8)$ \\
\hline $\begin{array}{l}\text { Dependent } \\
\text { variable }\end{array}$ & Baseline & $\begin{array}{c}\text { GARCH- } \\
\text { implied } \\
\text { volatility }\end{array}$ & $\begin{array}{l}\text { Initial } \\
\text { forecast } \\
\text { revision }\end{array}$ & $\begin{array}{c}\text { Final } \\
\text { forecast } \\
\text { revision }\end{array}$ & $\begin{array}{c}\text { Average of } \\
\text { monthly inflation } \\
\text { Forecast Errors } \\
\text { (current year) }\end{array}$ & $\begin{array}{c}\text { Standard deviation of } \\
\text { monthly inflation } \\
\text { forecast errors } \\
\text { (current year) }\end{array}$ & $\begin{array}{c}\text { Average of } \\
\text { monthly inflation } \\
\text { Forecast Errors } \\
\text { (year ahead) }\end{array}$ & $\begin{array}{l}\text { Standard deviation } \\
\text { of monthly inflation } \\
\text { forecast errors } \\
\text { (current year) }\end{array}$ \\
\hline \multicolumn{9}{|l|}{ Regressors } \\
\hline dep.var. (-1) & $\begin{array}{c}0.705^{* * *} \\
(0.029)\end{array}$ & $\begin{array}{c}0.730^{* * * *} \\
(0.027)\end{array}$ & $\begin{array}{c}0.101 * * \\
(0.044)\end{array}$ & $\begin{array}{c}0.114^{* *} \\
(0.047)\end{array}$ & $\begin{array}{l}-0.054^{*} \\
(0.031)\end{array}$ & $\begin{array}{c}0.190^{* * * * *} \\
(0.021)\end{array}$ & $\begin{array}{c}0.100^{\text {***** }} \\
(0.039)\end{array}$ & $\begin{array}{c}0.042^{* * * * *} \\
(0.012)\end{array}$ \\
\hline inflation & $\begin{array}{c}0.121 * * * \\
(0.008)\end{array}$ & $\begin{array}{c}-0.022 * * * \\
(0.003)\end{array}$ & $\begin{array}{c}8.149 * * * \\
(1.155)\end{array}$ & $\begin{array}{c}13.087 * * * * \\
(1.550)\end{array}$ & $\begin{array}{c}32.471 * * * \\
(1.856)\end{array}$ & $\begin{array}{c}16.208 * * * \\
(1.269)\end{array}$ & $\begin{array}{c}5.302 \\
(3.293)\end{array}$ & $\begin{array}{c}9.829 * * * \\
(0.695)\end{array}$ \\
\hline fiscal stance & $\begin{array}{c}0.033 * * * \\
(0.010)\end{array}$ & $\begin{array}{c}0.012 * * * \\
(0.004)\end{array}$ & $\begin{array}{c}0.051^{* * * *} \\
(0.016)\end{array}$ & $\begin{array}{c}0.036 \\
(0.022)\end{array}$ & $\begin{array}{c}0.124 * * * \\
(0.037)\end{array}$ & $\begin{array}{c}0.041 * * \\
(0.019)\end{array}$ & $\begin{array}{l}0.079^{*} \\
(0.044)\end{array}$ & $\begin{array}{c}0.039^{* * * *} \\
(0.010)\end{array}$ \\
\hline output gap & $\begin{array}{c}0.023 * * * \\
(0.009)\end{array}$ & $\begin{array}{c}0.013 * * * \\
(0.004)\end{array}$ & $\begin{array}{c}0.029 \\
(0.021)\end{array}$ & $\begin{array}{c}0.084 * * * \\
(0.028)\end{array}$ & $\begin{array}{c}0.221 * * * * \\
(0.047)\end{array}$ & $\begin{array}{c}0.131 * * * * \\
(0.028)\end{array}$ & $\begin{array}{c}0.151^{* *} * \\
(0.062)\end{array}$ & $\begin{array}{c}0.077 * * * \\
(0.015)\end{array}$ \\
\hline gov.expenditures & $\begin{array}{l}-0.004 \\
(0.006)\end{array}$ & $\begin{array}{l}-0.001 \\
(0.003)\end{array}$ & $\begin{array}{c}0.004 \\
(0.010)\end{array}$ & $\begin{array}{c}0.012 \\
(0.014)\end{array}$ & $\begin{array}{c}0.014 \\
(0.021)\end{array}$ & $\begin{array}{c}0.011 \\
(0.012)\end{array}$ & $\begin{array}{l}-0.006 \\
(0.027)\end{array}$ & $\begin{array}{c}0.001 \\
(0.006)\end{array}$ \\
\hline sd NEER (-1) & $\begin{array}{c}0.019 * * * \\
(0.002)\end{array}$ & $\begin{array}{l}-0.000 \\
(0.001)\end{array}$ & $\begin{array}{c}-0.011 * * * \\
(0.002)\end{array}$ & $\begin{array}{c}-0.006^{* *} * \\
(0.003)\end{array}$ & $\begin{array}{c}0.038^{* * * *} \\
(0.005)\end{array}$ & $\begin{array}{c}0.020 * * * * \\
(0.003)\end{array}$ & $\begin{array}{c}0.077 \text { *** } \\
(0.007)\end{array}$ & $\begin{array}{c}0.009 * * * \\
(0.002)\end{array}$ \\
\hline imports_gdp (-1) & $\begin{array}{l}-0.001 \\
(0.003)\end{array}$ & $\begin{array}{c}0.002 \\
(0.001)\end{array}$ & $\begin{array}{c}-0.014 * * * \\
(0.005)\end{array}$ & $\begin{array}{c}-0.018^{* *} \\
(0.008)\end{array}$ & $\begin{array}{l}-0.011 \\
(0.011)\end{array}$ & $\begin{array}{c}-0.018 * * * \\
(0.007)\end{array}$ & $\begin{array}{c}-0.001 \\
(0.015)\end{array}$ & $\begin{array}{c}-0.009 * * * \\
(0.004)\end{array}$ \\
\hline Observations & 848 & 912 & 548 & 525 & 617 & 616 & 617 & 616 \\
\hline$R$-squared & 0.848 & 0.755 & 0.414 & 0.477 & 0.542 & 0.690 & 0.534 & 0.673 \\
\hline
\end{tabular}

Note: OLS regression with different proxies for the dependent variable as identified in the second row. Time and country effects included but omitted. Robust standard errors in parenthesis. *, **, *** denote statistical significance at the 10,5, and 1 percent levels, respectively. Constant term was estimated by omitted for reasons of parsimony. 
Table 6: Price Volatility and Fiscal Discretion (measured as the absolute value of fiscal stance), alternative dependent variables, by income group

\begin{tabular}{|c|c|c|c|c|c|c|c|c|c|c|c|c|c|c|c|c|}
\hline Specification & (1) & (2) & (3) & (4) & (5) & (6) & (7) & $(8)$ & (9) & (10) & (11) & (12) & (13) & (14) & (15) & (16) \\
\hline $\begin{array}{l}\text { Dependent } \\
\text { variable }\end{array}$ & \multicolumn{2}{|c|}{ Baseline } & \multicolumn{2}{|c|}{$\begin{array}{l}\text { GARCH-implied } \\
\text { volatility }\end{array}$} & \multicolumn{2}{|c|}{$\begin{array}{l}\text { Initial forecast } \\
\text { revision }\end{array}$} & \multicolumn{2}{|c|}{ Final forecast revision } & \multicolumn{2}{|c|}{$\begin{array}{l}\text { Average of monthly } \\
\text { inflation Forecast } \\
\text { Errors (current year) }\end{array}$} & \multicolumn{2}{|c|}{$\begin{array}{c}\text { Standard deviation of } \\
\text { monthly inflation } \\
\text { forecast errors (current } \\
\text { year) } \\
\end{array}$} & \multicolumn{2}{|c|}{$\begin{array}{l}\text { Average of monthly } \\
\text { inflation Forecast } \\
\text { Errors (year ahead) }\end{array}$} & \multicolumn{2}{|c|}{$\begin{array}{c}\text { Standard deviation of } \\
\text { monthly inflation } \\
\text { forecast errors (current } \\
\text { year) }\end{array}$} \\
\hline Income group & $\mathrm{AE}$ & EM & $\mathrm{AE}$ & EM & $\mathrm{AE}$ & EM & $\mathrm{AE}$ & EM & $\mathrm{AE}$ & EM & $\mathrm{AE}$ & EM & $\mathrm{AE}$ & EM & $\mathrm{AE}$ & EM \\
\hline Regressors & & & & & & & & & & & & & & & & \\
\hline dep.var. (-1) & $\begin{array}{c}0.9266^{* * * *} \\
(0.036)\end{array}$ & $\begin{array}{c}0.486 * * * \\
(0.067)\end{array}$ & $\begin{array}{c}0.647 * * * * \\
(0.043)\end{array}$ & $\begin{array}{c}0.702 * * * \\
(0.044)\end{array}$ & $\begin{array}{c}0.052 \\
(0.051)\end{array}$ & $\begin{array}{c}0.138 \\
(0.094)\end{array}$ & $\begin{array}{l}-0.012 \\
(0.050)\end{array}$ & $\begin{array}{c}0.158 \\
(0.099)\end{array}$ & $\begin{array}{c}0.056 \\
(0.048)\end{array}$ & $\begin{array}{l}-0.040 \\
(0.054)\end{array}$ & $\begin{array}{c}0.094 * * \\
(0.045)\end{array}$ & $\begin{array}{c}0.189^{* * * *} \\
(0.039)\end{array}$ & $\begin{array}{c}0.106 * * \\
(0.053)\end{array}$ & $\begin{array}{c}0.101 \\
(0.080)\end{array}$ & $\begin{array}{c}0.036 \\
(0.044)\end{array}$ & $\begin{array}{c}0.031 \\
(0.022)\end{array}$ \\
\hline inflation & $\begin{array}{c}0.100 * * * * \\
(0.010)\end{array}$ & $\begin{array}{c}0.132 * * * \\
(0.016)\end{array}$ & $\begin{array}{c}0.001 \\
(0.001)\end{array}$ & $\begin{array}{c}-0.019 * * * \\
(0.006)\end{array}$ & $\begin{array}{l}-1.354 \\
(1.559)\end{array}$ & $\begin{array}{c}10.152^{* * * *} \\
(2.442)\end{array}$ & $\begin{array}{l}3.788^{*} \\
(1.948)\end{array}$ & $\begin{array}{c}17.317 * * * \\
(3.615)\end{array}$ & $\begin{array}{c}0.598 \\
(0.999)\end{array}$ & $\begin{array}{c}37.187 * * * \\
(3.520)\end{array}$ & $\begin{array}{l}1.599 * * \\
(0.715)\end{array}$ & $\begin{array}{c}22.338 * * * \\
(2.670)\end{array}$ & $\begin{array}{c}9.064 * * * * \\
(2.774)\end{array}$ & $\begin{array}{c}7.461 \\
(7.877)\end{array}$ & $\begin{array}{c}1.455 * * * * \\
(0.525)\end{array}$ & $\begin{array}{c}13.813^{* * * *} \\
(1.436)\end{array}$ \\
\hline fiscal stance & $\begin{array}{c}0.010 \\
(0.007)\end{array}$ & $\begin{array}{c}0.067 * * \\
(0.027)\end{array}$ & $\begin{array}{c}0.001 * * \\
(0.001)\end{array}$ & $\begin{array}{c}0.038 * * * \\
(0.013)\end{array}$ & $\begin{array}{l}-0.003 \\
(0.009)\end{array}$ & $\begin{array}{c}0.172 * * * * \\
(0.053)\end{array}$ & $\begin{array}{l}-0.017 \\
(0.013)\end{array}$ & $\begin{array}{c}0.164 * * \\
(0.079)\end{array}$ & $\begin{array}{l}-0.006 \\
(0.010)\end{array}$ & $\begin{array}{c}0.262^{* *} \\
(0.109)\end{array}$ & $\begin{array}{c}0.000 \\
(0.006)\end{array}$ & $\begin{array}{l}-0.000 \\
(0.053)\end{array}$ & $\begin{array}{c}0.032 \\
(0.024)\end{array}$ & $\begin{array}{c}0.044 \\
(0.124)\end{array}$ & $\begin{array}{l}-0.001 \\
(0.005)\end{array}$ & $\begin{array}{c}0.045 \\
(0.027)\end{array}$ \\
\hline output gap & $\begin{array}{c}0.029 * * * \\
(0.008)\end{array}$ & $\begin{array}{c}0.040^{* * *} \\
(0.020)\end{array}$ & $\begin{array}{c}0.000 \\
(0.001)\end{array}$ & $\begin{array}{c}0.009 \\
(0.009)\end{array}$ & $\begin{array}{l}0.027^{*} \\
(0.015)\end{array}$ & $\begin{array}{c}0.059 \\
(0.054)\end{array}$ & $\begin{array}{l}0.034 * \\
(0.019)\end{array}$ & $\begin{array}{c}0.169^{* *} \\
(0.075)\end{array}$ & $\begin{array}{l}-0.007 \\
(0.014)\end{array}$ & $\begin{array}{c}0.390 * * * * \\
(0.113)\end{array}$ & $\begin{array}{l}-0.012 \\
(0.010)\end{array}$ & $\begin{array}{c}0.235^{* * * *} \\
(0.061)\end{array}$ & $\begin{array}{c}0.032 \\
(0.040)\end{array}$ & $\begin{array}{l}0.252^{*} \\
(0.140)\end{array}$ & $\begin{array}{c}0.020^{* * * *} \\
(0.008)\end{array}$ & $\begin{array}{c}0.139 * * * \\
(0.031)\end{array}$ \\
\hline gov.expenditures & $\begin{array}{l}-0.000 \\
(0.001)\end{array}$ & $\begin{array}{l}-0.047 * \\
(0.027)\end{array}$ & $\begin{array}{c}-0.001 * * * \\
(0.000)\end{array}$ & $\begin{array}{l}-0.014 \\
(0.011)\end{array}$ & $\begin{array}{c}0.005 \\
(0.005)\end{array}$ & $\begin{array}{l}-0.009 \\
(0.057)\end{array}$ & $\begin{array}{c}0.002 \\
(0.007)\end{array}$ & $\begin{array}{l}-0.034 \\
(0.088)\end{array}$ & $\begin{array}{c}0.004 \\
(0.005)\end{array}$ & $\begin{array}{c}0.048 \\
(0.089)\end{array}$ & $\begin{array}{l}-0.000 \\
(0.003)\end{array}$ & $\begin{array}{c}-0.113^{* * *} \\
(0.051)\end{array}$ & $\begin{array}{c}0.015 \\
(0.013)\end{array}$ & $\begin{array}{l}-0.012 \\
(0.122)\end{array}$ & $\begin{array}{l}-0.001 \\
(0.002)\end{array}$ & $\begin{array}{c}-0.067 * * \\
(0.026)\end{array}$ \\
\hline sd NEER (-1) & $\begin{array}{l}0.004 * \\
(0.002)\end{array}$ & $\begin{array}{c}0.040 * * * \\
(0.006)\end{array}$ & $\begin{array}{c}0.000 \\
(0.000)\end{array}$ & $\begin{array}{c}0.001 \\
(0.002)\end{array}$ & $\begin{array}{c}0.006 \\
(0.006)\end{array}$ & $\begin{array}{l}0.009^{*} \\
(0.005)\end{array}$ & $\begin{array}{l}-0.005 \\
(0.008)\end{array}$ & $\begin{array}{l}-0.003 \\
(0.007)\end{array}$ & $\begin{array}{l}-0.002 \\
(0.006)\end{array}$ & $\begin{array}{c}0.034 * * * * \\
(0.010)\end{array}$ & $\begin{array}{c}0.000 \\
(0.004)\end{array}$ & $\begin{array}{c}0.019^{* * * *} \\
(0.005)\end{array}$ & $\begin{array}{l}-0.022 \\
(0.015)\end{array}$ & $\begin{array}{c}0.075 * * * \\
(0.012)\end{array}$ & $\begin{array}{l}-0.000 \\
(0.003)\end{array}$ & $\begin{array}{c}0.008 * * * \\
(0.003)\end{array}$ \\
\hline imports_gdp (-1) & $\begin{array}{c}0.001 * * * \\
(0.000)\end{array}$ & $\begin{array}{l}-0.003 \\
(0.010)\end{array}$ & $\begin{array}{c}0.000 \\
(0.000)\end{array}$ & $\begin{array}{c}0.004 \\
(0.004)\end{array}$ & $\begin{array}{l}0.007 * * \\
(0.003)\end{array}$ & $\begin{array}{l}-0.018 \\
(0.019)\end{array}$ & $\begin{array}{c}0.010^{* * * *} \\
(0.004)\end{array}$ & $\begin{array}{c}0.029 \\
(0.033)\end{array}$ & $\begin{array}{l}0.005^{*} \\
(0.003)\end{array}$ & $\begin{array}{c}0.020 \\
(0.034)\end{array}$ & $\begin{array}{c}0.005^{* * * * *} \\
(0.002)\end{array}$ & $\begin{array}{c}0.075^{* * * *} \\
(0.021)\end{array}$ & $\begin{array}{c}0.009 \\
(0.008)\end{array}$ & $\begin{array}{c}0.027 \\
(0.051)\end{array}$ & $\begin{array}{l}0.003^{*} \\
(0.001)\end{array}$ & $\begin{array}{c}0.033 * * * \\
(0.011)\end{array}$ \\
\hline $\begin{array}{l}\text { Observations } \\
R \text {-squared }\end{array}$ & $\begin{array}{c}609 \\
0.814\end{array}$ & $\begin{array}{c}239 \\
0.850\end{array}$ & $\begin{array}{c}625 \\
0.752\end{array}$ & $\begin{array}{c}287 \\
0.796\end{array}$ & $\begin{array}{c}397 \\
0.352\end{array}$ & $\begin{array}{c}151 \\
0.484\end{array}$ & $\begin{array}{c}386 \\
0.354\end{array}$ & $\begin{array}{c}139 \\
0.497\end{array}$ & $\begin{array}{c}422 \\
0.194\end{array}$ & $\begin{array}{c}195 \\
0.602\end{array}$ & $\begin{array}{c}422 \\
0.461\end{array}$ & $\begin{array}{c}194 \\
0.780\end{array}$ & $\begin{array}{c}422 \\
0.434\end{array}$ & $\begin{array}{c}195 \\
0.589\end{array}$ & $\begin{array}{c}422 \\
0.468\end{array}$ & $\begin{array}{c}194 \\
0.767\end{array}$ \\
\hline
\end{tabular}

Note: OLS regression with different proxies for the dependent variable as identified in the second row. Time and country effects included but omitted. Subsampling analysis as identified in the third row: AE - advanced economies; EM - emerging countries. Robust standard errors in parenthesis. *, **, *** denote statistical significance at the 10,5, and 1 percent levels, respectively. Constant term was estimated by omitted for reasons of parsimony. 
Table 7: Price Volatility and Fiscal Discretion (measured as the absolute value of fiscal stance), recessions and financial crises

\begin{tabular}{|c|c|c|c|c|}
\hline Specification & (1) & (2) & (3) & (4) \\
\hline \multicolumn{5}{|l|}{ Regressors } \\
\hline dep.var. (-1) & $\begin{array}{c}0.538 * * * * \\
(0.020)\end{array}$ & $\begin{array}{c}0.394 * * * \\
(0.035)\end{array}$ & $\begin{array}{c}0.532 * * * * \\
(0.020)\end{array}$ & $\begin{array}{c}0.526 * * * \\
(0.020)\end{array}$ \\
\hline inflation & $\begin{array}{c}0.052 * * * \\
(0.007)\end{array}$ & $0.089 * * *$ & $\begin{array}{c}0.053 * * * * \\
(0.007)\end{array}$ & $\begin{array}{c}0.057 * * * * \\
(0.007)\end{array}$ \\
\hline fiscal stance & $\begin{array}{c}0.023^{* *} \\
(0.010)\end{array}$ & $\begin{array}{c}0.039 \\
(0.024)\end{array}$ & $\begin{array}{c}0.022 * * \\
(0.011)\end{array}$ & $\begin{array}{l}0.021^{*} \\
(0.011)\end{array}$ \\
\hline output gap & $\begin{array}{c}0.023^{* * *} \\
(0.009)\end{array}$ & $\begin{array}{l}0.028^{*} \\
(0.017)\end{array}$ & $\begin{array}{c}0.028 * * * * \\
(0.010)\end{array}$ & $\begin{array}{c}0.021^{* *} \\
(0.010)\end{array}$ \\
\hline gov.expenditures & $\begin{array}{l}-0.003 \\
(0.002)\end{array}$ & $\begin{array}{c}0.005 \\
(0.005)\end{array}$ & $\begin{array}{l}-0.003 \\
(0.002)\end{array}$ & $\begin{array}{l}-0.003 \\
(0.002)\end{array}$ \\
\hline sd NEER (-1) & $\begin{array}{c}0.023 * * * \\
(0.002)\end{array}$ & $\begin{array}{c}0.041 * * * * \\
(0.005)\end{array}$ & $\begin{array}{c}0.023 * * * * \\
(0.002)\end{array}$ & $\begin{array}{c}0.025 * * * \\
(0.002)\end{array}$ \\
\hline imports_gdp (-1) & $\begin{array}{c}0.004 * * * * \\
(0.001)\end{array}$ & $\begin{array}{c}0.004 * * * * \\
(0.001)\end{array}$ & $\begin{array}{c}0.004 * * * \\
(0.001)\end{array}$ & $\begin{array}{c}0.004 * * * \\
(0.001)\end{array}$ \\
\hline Recession* fiscal stance & $\begin{array}{c}0.100 * * * * \\
(0.032)\end{array}$ & & & \\
\hline Expansion* fiscal stance & $\begin{array}{c}-0.083 * * \\
(0.040)\end{array}$ & & & \\
\hline FC & & $\begin{array}{c}0.004 \\
(0.003)\end{array}$ & & \\
\hline FC* fiscal stance & & $\begin{array}{c}0.181 \\
(0.173)\end{array}$ & & \\
\hline banking & & & $\begin{array}{c}0.002 \\
(0.001)\end{array}$ & \\
\hline Banking* fiscal stance & & & $\begin{array}{l}0.158^{*} \\
(0.082)\end{array}$ & \\
\hline currency & & & & $\begin{array}{c}0.006^{* * *} \\
(0.003)\end{array}$ \\
\hline Currency* fiscal stance & & & & $\begin{array}{l}0.196^{*} \\
(0.102)\end{array}$ \\
\hline Observations & 848 & 282 & 848 & 848 \\
\hline$R$-squared & 0.775 & 0.747 & 0.775 & 0.775 \\
\hline
\end{tabular}

Note: OLS regression. Time and country effects included but omitted. "FC" denotes overall financial crises. Robust standard errors in parenthesis. *, **, *** denote statistical significance at the 10,5, and 1 percent levels, respectively. Constant term was estimated by omitted for reasons of parsimony. 
Table 8: Price Volatility and Fiscal Discretion, asymmetric effects to fiscal expansions and consolidations

\begin{tabular}{|c|c|c|c|c|c|c|}
\hline Specification & (1) & (2) & (3) & (4) & (5) & (6) \\
\hline $\begin{array}{l}\text { Changes in fiscal } \\
\text { stance }\end{array}$ & negative & positive & negative & positive & negative & positive \\
\hline \multicolumn{7}{|l|}{ Regressors } \\
\hline $\begin{array}{l}\text { dep.var. (-1) } \\
\text { dep.var. (-2) }\end{array}$ & $\begin{array}{c}0.314 * * * \\
(0.028)\end{array}$ & $\begin{array}{c}0.664 * * * \\
(0.033)\end{array}$ & $\begin{array}{c}0.606 * * * \\
(0.035)\end{array}$ & $\begin{array}{c}0.775 * * * \\
(0.037)\end{array}$ & $\begin{array}{c}0.639 * * * \\
(0.041) \\
-0.042 \\
(0.026)\end{array}$ & $\begin{array}{c}0.966 * * * \\
(0.045) \\
-0.262 * * * \\
(0.039)\end{array}$ \\
\hline inflation & $\begin{array}{c}0.109 * * * \\
(0.013)\end{array}$ & $\begin{array}{c}0.033 * * * \\
(0.010)\end{array}$ & $\begin{array}{c}0.217 * * * \\
(0.017)\end{array}$ & $\begin{array}{c}0.065^{* * * *} \\
(0.013)\end{array}$ & $\begin{array}{c}0.219^{* * * *} \\
(0.017)\end{array}$ & $\begin{array}{c}0.083 * * * \\
(0.012)\end{array}$ \\
\hline inflation (-1) & & & $\begin{array}{c}-0.165^{* * * *} \\
(0.015)\end{array}$ & $\begin{array}{c}- \\
0.080 * * * \\
(0.013)\end{array}$ & $\begin{array}{c}- \\
0.164 * * * \\
(0.015)\end{array}$ & $-0.070 * * *$ \\
\hline fiscal stance & $\begin{array}{c}0.041 * * \\
(0.019)\end{array}$ & $\begin{array}{c}0.016 \\
(0.026)\end{array}$ & $\begin{array}{c}0.053 * * \\
(0.022)\end{array}$ & $\begin{array}{c}0.013 \\
(0.019)\end{array}$ & $\begin{array}{c}0.059 * * * \\
(0.023)\end{array}$ & $\begin{array}{c}0.002 \\
(0.018)\end{array}$ \\
\hline output gap & $\begin{array}{l}0.030^{*} \\
(0.017)\end{array}$ & $\begin{array}{c}0.034 * * * \\
(0.012)\end{array}$ & $\begin{array}{l}0.030^{*} \\
(0.018)\end{array}$ & $\begin{array}{c}0.043 * * * \\
(0.015)\end{array}$ & $\begin{array}{l}0.033^{*} \\
(0.018)\end{array}$ & $\begin{array}{c}0.046^{* * * *} \\
(0.014)\end{array}$ \\
\hline gov.expenditures & $\begin{array}{l}-0.003 \\
(0.010)\end{array}$ & $\begin{array}{l}-0.007 \\
(0.008)\end{array}$ & $\begin{array}{l}-0.003 \\
(0.010)\end{array}$ & $\begin{array}{l}-0.007 \\
(0.008)\end{array}$ & $\begin{array}{l}-0.002 \\
(0.010)\end{array}$ & $\begin{array}{l}-0.001 \\
(0.008)\end{array}$ \\
\hline sd NEER (-1) & $\begin{array}{c}0.042^{* * * *} \\
(0.003)\end{array}$ & $\begin{array}{c}0.016^{* * * *} \\
(0.003)\end{array}$ & $\begin{array}{c}0.026^{* * * *} \\
(0.003)\end{array}$ & $\begin{array}{l}0.007 * \\
(0.004)\end{array}$ & $\begin{array}{c}0.026 * * * \\
(0.003)\end{array}$ & $\begin{array}{l}0.006^{*} \\
(0.003)\end{array}$ \\
\hline imports_gdp (-1) & $\begin{array}{l}-0.002 \\
(0.006)\end{array}$ & $\begin{array}{c}0.004 \\
(0.004)\end{array}$ & $\begin{array}{l}-0.003 \\
(0.006)\end{array}$ & $\begin{array}{c}0.002 \\
(0.005)\end{array}$ & $\begin{array}{l}-0.003 \\
(0.006)\end{array}$ & $\begin{array}{l}-0.001 \\
(0.005)\end{array}$ \\
\hline Observations & 415 & 432 & 415 & 432 & 415 & 432 \\
\hline$R$-squared & 0.829 & 0.854 & 0.896 & 0.884 & 0.897 & 0.897 \\
\hline
\end{tabular}

Note: OLS regression. Time and country effects included but omitted. Positive/negative changes in the fiscal stance identified in the second row. Robust standard errors in parenthesis. *,**,*** denote statistical significance at the 10, 5, and 1 percent levels, respectively. Constant term was estimated by omitted for reasons of parsimony. 


\section{APPENDIX}

\section{List of countries}

United States, United Kingdom, Austria, Belgium, Denmark, France, Germany, Italy, Netherlands, Norway, Sweden, Switzerland, Canada, Japan, Finland, Greece, Iceland, Ireland, Portugal, Spain, Turkey, ,Australia , New Zealand, South Africa, Argentina, Brazil, Chile, Colombia, Mexico, Peru, ,Israel ,Jordan, Egypt, Hong Kong SAR, India, Indonesia, Korea, Malaysia, Philippines, Singapore, Thailand, Morocco, Bulgaria, Russia, China, Ukraine, Czech Republic, Slovak Republic, Hungary, Lithuania, Slovenia, Poland, Romania.

Table A1: Correlation between measures of inflation volatility

\begin{tabular}{|l|c|}
\hline Correlation coefficients & $\begin{array}{c}\text { 5-year rolling standard } \\
\text { deviation of inflation }\end{array}$ \\
\hline GARCH(1,1) implied volatility & $0.0906^{* * *}$ \\
\hline 12 average of inflation forecast errors (current year) & $0.1633^{* * *}$ \\
\hline 12 standard deviation of inflation forecast errors (current year) & $0.582^{* * *}$ \\
\hline 12 average of inflation forecast errors (year ahead) & $0.3146^{* * *}$ \\
\hline 12 standard deviation of inflation forecast errors (year ahead) & $0.5206^{* * *}$ \\
\hline Final forecast revision & $0.2812^{* * *}$ \\
\hline Initial forecast revision & $0.2352^{* * *}$ \\
\hline
\end{tabular}

Note: $* * *$ denote statistical significant at the 1 percent level.

Table A2: Summary Statistics

\begin{tabular}{|c|c|c|c|c|c|}
\hline Variable & Obs & Mean & Std. Dev. & Min & Max \\
\hline inflation volatility & 1,019 & 0.016658 & 0.01706 & 0.001392 & 0.205277 \\
\hline \multirow{3}{*}{$\begin{array}{l}\text { inflation } \\
\text { Fiscal stance (absolute value of annual } \\
\text { changes in CAPB) } \\
\text { Fiscal stance (5-year rolling standard } \\
\text { deviation of CAPB) }\end{array}$} & 1,108 & 0.044474 & 0.0468 & -0.03815 & 0.619187 \\
\hline & 1,073 & 1.310908 & 1.435464 & 0 & 20.5957 \\
\hline & 902 & 1.543344 & 1.119784 & $2.56 \mathrm{E}-10$ & 9.860977 \\
\hline \multirow{4}{*}{$\begin{array}{l}\text { Output gap } \\
\text { Government expenditures (percent of } \\
\text { GDP) } \\
5 \text {-year rolling standard deviation of broad } \\
\text { money } \\
5 \text {-year rolling standard deviation of } \\
\text { nominal effective exchange rate }\end{array}$} & 1,127 & 0.021269 & 1.824712 & -10.2761 & 11.16313 \\
\hline & 1,050 & 0.389251 & 0.119925 & 0.107028 & 0.709883 \\
\hline & 811 & 5.296203 & 4.8729 & 0.149778 & 28.29758 \\
\hline & 1,019 & 6.661725 & 12.99533 & 0.478694 & 158.9453 \\
\hline \multirow{2}{*}{$\begin{array}{l}\text { Imports (percent of GDP) } \\
\text { GARCH }(1,1) \text { implied volatility }\end{array}$} & 1,127 & 41.63763 & 30.93237 & 6.866724 & 228.9812 \\
\hline & 1,127 & 0.00103 & 0.004479 & $9.07 \mathrm{E}-05$ & 0.096468 \\
\hline \multirow{2}{*}{$\begin{array}{l}12 \text { average of inflation forecast errors } \\
\text { (current year) } \\
12 \text { standard deviation of inflation forecast } \\
\text { errors (current year) } \\
12 \text { average of inflation forecast errors }\end{array}$} & 685 & -0.03016 & 2.164524 & -38.6369 & 24.99033 \\
\hline & 684 & 0.556557 & 2.003816 & 0.031151 & 42.79421 \\
\hline $\begin{array}{l}12 \text { average of inflation forecast errors } \\
\text { (year ahead) }\end{array}$ & 685 & 0.067508 & 3.40752 & -18.3471 & 53.30989 \\
\hline $\begin{array}{l}12 \text { standard deviation of inflation forecast } \\
\text { errors (year ahead) }\end{array}$ & 684 & 0.425946 & 1.849656 & 0.029315 & 45.93566 \\
\hline Final forecast revision & 598 & 0.051123 & 1.170511 & -13.9086 & 7.74174 \\
\hline Initial forecast revision & 587 & 0.194499 & 3.403151 & -18.3861 & 62.80327 \\
\hline
\end{tabular}

